\title{
The ICT Influence on Strategic Thinking. Particularities in the Oil and Gas Industry
}

\author{
Dan Andrei Panduru, FAIMA Doctoral School, University "Politehnica" of Bucharest, Romania, \\ andrei_panduru91@yahoo.com \\ Cezar Scarlat, FAIMA Doctoral School, University "Politehnica" of Bucharest, Romania, \\ cezarscarlat@yahoo.com
}

Mihai Liviu Gherman, FAIMA Doctoral School, University "Politehnica" of Bucharest, Romania, mihai.liviu1964@yahoo.com

\begin{abstract}
The oil and gas industry is of key-importance in the energy sector. Therefore, the focus of this paper is on particularities of the strategic thinking in the contemporary oil and gas industry, presented on the background of the evolution of strategic thinking to-date. More specifically, there is a third perspective (dimension of the study): the influence of the dynamic information and communication technology (ICT) on strategic thinking in the above-mentioned industry, mainly at the organization level. The methodological approach is mainly secondary research (literature survey and specific studies conducted in oil and gas industry) as well as primary research (authors 'recent experience and observations as far as top management and oil and gas industry). This paper underlines some of the early stage findings - mostly qualitative - as part of larger doctoral research project. Four defining characteristics of the Industry 4.0 are presented, specifically applied to the oil and gas industry, with the perspective of the Industrial Internet of Things (IIoT), as well as the top five drivers of the digital transformation: manufacturing execution system, cloud computing, energy analytics, internet of things (IoT), and machine learning technologies designed for operations efficiency and sustainability. The findings have managerial implications for top managers and strategists involved in decision making process in companies active in the oil and gas industry. They face the challenge of adapting the organization strategy and solving the problem of improving the operational efficiency, concurrently reducing the environment carbon footprint - which requires huge investments to be made in digitalization of operations. As research in progress, the paper has inherent limitations; next step aiming at getting more quantitative results, by opening future research paths both longitudinally and transversally in oil and gas industry. If ICT solutions are used as a response to the organization's dynamic challenges, and if strategic thinking represents the mental process of finding opportunities to achieve the organization's goals, then conclusion is that ICT continuously does influence strategic thinking in the oil and gas industry.
\end{abstract}

Keywords: Strategic thinking, Organization strategy, Information \& Communication Technology (ICT), Industry 4.0, Industrial Internet of Things (IIoT), Oil and gas industry

\section{Introduction}

From state administrations and military structures of ancient times to early management pioneers to gurus of schools of strategic thinking as they are known today, the practice and corresponding theory of strategy has evolved and became increasingly complex over time. However, the literature on strategic management is of more recent date; as the short history of scientific management is just about a century old, the literature on strategic management is half-century its junior. 


\section{Issues in Information Systems}

Volume 22, Issue 1, pp. 269-281, 2021

Interestingly, while the history of scientific management started with the seminal works of Taylor (1911), Gantt (1916) and Fayol (1917), in 1911 Harvard Business School introduced for the first time a course designed to improve strategic skills of general managers, named "Business Policy", which later, in 1969, became a mandatory course for all American business schools (Kazmi and Kazmi, 1992).

The schools of management thought have evolved along the twentieth century - Peter Drucker is considered the founder of modern management, authoring influential books on management (Drucker, $1954 ; 1964 ; 1971 ; 1985)$ in the larger technology and socio-economic context - and have culminated in the second part of the last century with successful theories on strategic management, associated with concepts as strategy, strategic thinking, strategic planning and strategic plan as well as dominant figures of scholars like Alfred Chandler-Jr. (1962), Harry Igor Ansoff $(1965 ; 1979 ; 1987 ; 1988)$ and his followers (Ansoff and Antoniou, 2006; Martinet, 2010; Moussetis, 2011; Ansoff et al., 2019), Michael Porter (1986; 1996), Henry Mintzberg (1987; 1994; 2013).

The turbulent politico-economic environment that signaled the new millennium (Drucker, 1980) and emergence of the "time of great change" (Drucker, 1995; Hamel and Prahalad, 1994), characterized by dissolution of many centrally planned economies, global crises (economic and financial, energy and environment) as well as political conflicts has demonstrated that rigidity associated with the strategic planning could not provide viable management solutions anymore. Thus, newer types of more flexible schools of thought - still strategic - started to gain ground among top managers and strategists: foresight in all sectors, mostly at the macro level (Loveridge, 2003; Popper, 2008), marketing as a strategy (Kumar, 2004), and blue ocean strategy in business primarily (Kim and Mauborgne, 2004). Currently, the lineage of strategic thinking culminates with digital transformation. Turbulent and more dynamic environment that preceded it contributed to its emergence.

A history - even a summary of strategic thinking and thinkers - is beyond the scope of this paper; yet framing the background is important, in order to understand the context of the focus of this study: contemporary oil industry as well as the role played by the rapid development of the information and communication technologies (ICT) in adapting the strategic thinking to the peculiarities of this important sector of the economy.

Consequently, the remaining of this paper is structured as follows: strategic thinking and its main schools; research methodology; ICT influence on strategic thinking and its particularities in the oil industry; followed by conclusions and managerial implications as well as limitations and further research paths.

\section{Strategic thinking and its main schools}

According to Mintzberg (1994), strategic thinking represents a high level perspective over the organization, a synthesis of the hard data and personal skills. Wootton and Home (2000) argue that strategic thinking rely on formulating and evaluating ideas, and building the action plan based on information collected and analyzed in this scope (Figure 1).

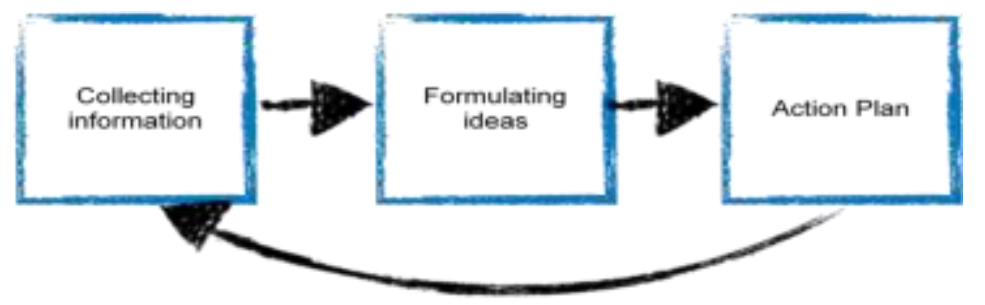

Figure 1. Simplified scheme of the process of strategic thinking. Adapted after: Wootton \& Home (2000) From the perspective of Haycock, Cheadle and Bluestone (2012), strategic thinking represents an innovative and creative process of thinking leading to solutions for the most unpredictable challenges. 


\section{Issues in Information Systems}

Volume 22, Issue 1, pp. 269-281, 2021

Heracleous (1998, p.485) argues that the scope of the strategic thinking is "to discover novel, imaginative strategies which can rewrite the rules of the competitive game, and to envision potential futures significantly different from the present", while Goldman (2012) considers that strategic thinking can be mainly find in literature as part of strategy development, as a perspective and mental processing.

Yet criticized earlier by Ansoff (1991), mainly for inconsistency of criteria, as well as by Shekhar (2009), Mintzberg, Ahlstrand and Lampel (1998) provide a comprehensive synthesis of the schools of strategic thinking, grouped in ten categories, as shortly described below.

The design school, pioneered by Chandler Jr. (1962) and his followers, considers strategy as a process of conception. The main concepts of design school are related to the strategy creation based on organization's strong and weak points as well as its internal and external environment (SWOT analysis), which might have its own traps as well (Scarlat, 2015; Popescu and Scarlat, 2015).

The environmental school considers strategy formulation as a reactive process, built on the premise of adaptation to the external environmental to ensure the company survival.

In the planning school, the formulation of strategy is a formal process. In Ansoff's view, strategic planning is represented by a general plan which is cascaded in the organization to more specific medium and short period plans (Ansoff, 1965).

The positioning school assumes that strategy formulation is an analytical process, aiming at positioning on the market, versus competitors. Porter (1980) is the main theorist, developing the concepts of the former two schools; he formulates the generic strategies in order to determine the organizations competitive advantage.

The entrepreneurial school (strategy formulation as visionary process) is based on the leader's vision, experience and intuition. It was criticized by Shekhar (2009) as dependency on a single leader might be a risky.

As opposed to the entrepreneurial school, the perspective of the power school is building the strategy on negotiation between the most influential groups inside and outside the organization. Nevertheless, Shekhar (2009) mentions the negative impact of self-interest negotiation process.

The school of culture is also opposed to individual power, as it favours strategy building as collective process; strategy is the result of social interactions in the organization, aspiring to the common interest.

The cognitive school (process of strategy formulation as a mental process) is based on previous experiences and knowledge gained by those responsible for this process. The main limitation is exactly because of their limited ability to assimilate and use all available information.

Learning school considers the process of strategy formulation as a learning process. The advantage of adaptability is counter-balanced by the "learning myopia" (Levinthal and March, 1993) that consists in lack of longer term perspectives of the strategy.

The configuration school supports strategy formulation as a transformative process: the strategy can go through each Mintzberg's school, depending on the circumstances and phase of the organization's development. Satell (2020) argues that most important aspect of this transformative process is to act considering the organization's environment, not impulsively.

The different schools of strategic thinking operate in practice inter-related, mixed up and/or combined, sometimes even overlapping. Kaplan and Norton (2001) have brought to relevance the company indicators and Doer (2018) theorized the goal-setting system (also known as OKRs - Objectives and Key Results). 


\section{Issues in Information Systems}

Volume 22, Issue 1, pp. 269-281, 2021

The system described was applied in 60s by Andy Grove at Intel, based on a simplified, more flexible and practical version of strategy theories, which were previously described by Drucker (1954) and Ansoff (1965).

All schools of strategic thought have contributed to the development of strategic management, and management in general. However, the global turbulences of the politico-economic environment (which were signaled by strategy gurus, looking to find new ways to solve the managerial challenges, as shown above), paralleled by explosive development of the information and communication technologies (ICT), have made obvious that rigid strategic planning cannot cope with new challenges and is not able to provide viable management solutions anymore. Amid the newer types of more flexible strategic schools of thought - either macro- (as foresight) or micro- (as blue ocean or marketing as a strategy) - the current line of strategic thinking is associated with digital transformation.

As Schwab (2017) observes, the digital technologies are not new, but - as compared to the third industrial revolution - they are becoming more sophisticated and integrated; as result, they are transforming societies and the global economy. In the oil and gas industry, digitalization represents a critical point because of its important role in the process of "energy transition"; therefore, digitalization should be among "the strategic priorities for the organization in the future" (Dickson, 2021, p.5). More than this, it is important to underline that, in terms of strategic thinking, digitalization (or digital transformation) can be achieved only by strategic decisions that could be made only as result of systematic strategic thinking - because implementation of the digital technologies can be completed only by significant, integrated investments required by the expensive ICT equipment and associated know-how. The digital transformation is the new strategic way of thinking, not only in the oil and gas industry (Scarlat and Stănciulescu, 2021; Scarlat, Stănciulescu and Panduru, 2021).

\section{Research methodology}

This study, as explorative essay, is just the inception phase of a larger research project in progress. It aims at portraying the status of the Romanian oil and gas industry in the larger framework of the global context of this industry, from that standpoint of the process of digital transformation and its associated digital technologies.

Mostly qualitative, this study is based mostly on secondary research (survey of literature, studies and reports on oil and gas industry). However, the secondary data were completed by significant information collected by primary research (interviews with industry experts). Specifically, in early 2020 a panel of experts (professionals from oil and gas industry) was assembled. A number of 13 interviews were conducted with nine executives and four consultants from Romanian oil and gas industry. Unfortunately, the coronavirus pandemic has made the continuation of interviews difficult.

Selective results of the interviews - related to the implementation stage of the digital key-technologies by two prominent Romanian oil and gas companies - are presented. Then, the results are compared to a global statistics resulting from a recent study completed by a top international consulting firm that investigated more than 200 companies (Pandey and Branson, 2020).

1. ICT influence on strategic thinking and its particularities in the oil and gas industry

The permanently increasing interest in technology and digitalization shown by business environment led to a new concept named as Industry 4.0, which represents the fourth industrial revolution. Schwab (2017) highlights that even the digital technologies are not new, they become more sophisticated and integrated, transforming societies and the global economy entirely.

The conceptual transition from the defining characteristics of the Industry 4.0 to the practical implementation of the novel digital technologies (i.e. digital transformation) is a process that can be accomplished by strategic thinking only - followed by strategic decisions (long-term, impacting all 


\section{Issues in Information Systems}

Volume 22, Issue 1, pp. 269-281, 2021

company functions as well as company activity entirely) - consequently involving considerable investments. Actually, the industry professionals as well as global consulting companies (Geissbauer, Vedso and Schrauf, 2016) undeniably acknowledge the industry 4.0 as a novel strategy (the Strategy 4.0) as such.

Montanus (2016, p.2) defines Industry 4.0 as a "new wave of technological development" which lead the organizations to redesign their business model. According to Fraser, Anastaselos and Ravikumar (2018), Industry 4.0 creates smart networks by connecting machines, systems, individuals and products.

Schlaepfer, Koch and Merkofer (2015) have identified four defining characteristics of Industry 4.0 (Figure 2):

(i) The "vertical networking of smart production systems" refers to production and maintenance management through cyber-physical production systems (CCPSs);

(ii) The "horizontal integration via a new generation of global value chain networks" means a flexible and transparent system for real-time networks and processes optimization;

(iii) "Through-engineering across the entire value chain" underlines the importance on focusing on entire product life cycle, from production process to end product;

(iv) "Acceleration through exponential technologies" is focused on the impact of the new developed solutions as autonomous solutions based on artificial intelligence (AI), drones for maintenance, 3D printers or nano-materials and nano-sensors.

All the above characteristics are not only applicable, but also met already in companies active in the oil and gas industry. The new ICTs create value for each company by optimizing costs and streamlining the business processes.

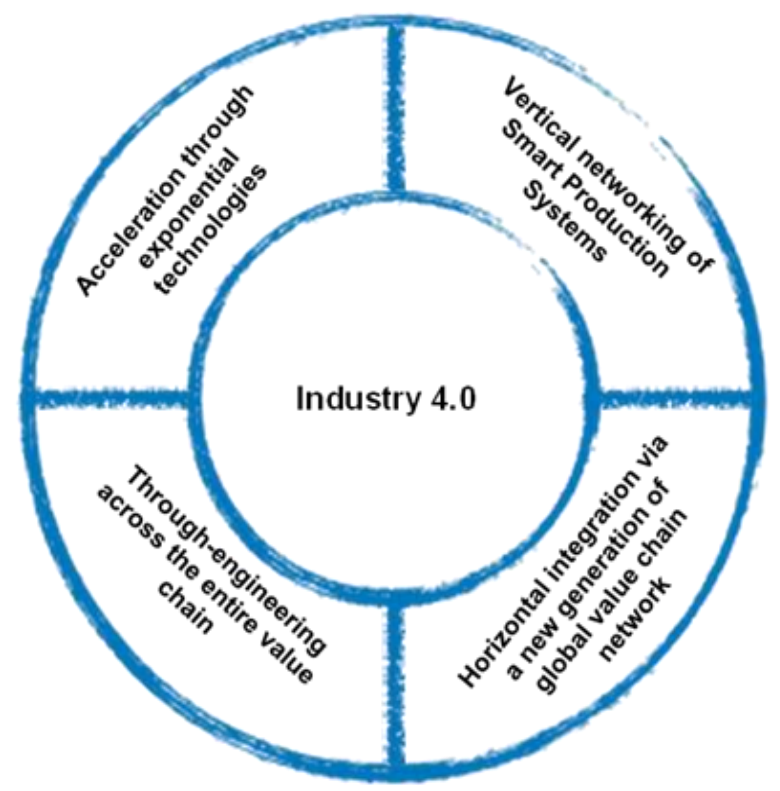

Figure 2. The four characteristics of the Industry 4.0. Adapted after: Schlaepfer, Koch \& Merkofer (2015)

Specifically, in the oil and gas industry, there is a big uncertainty regarding its future - as oil and gas organizations are in a difficult position to strategically plan the future, based on the multiple challenges they are facing. COVID-19 pandemic, political measures taken regarding climate change, electrical vehicles market increase and alike are factors that are forcing the leaders of oil and gas industry to respond quickly (make rapid decisions - which is somehow in contradiction with longer term strategic decisions). 


\section{Issues in Information Systems}

Volume 22, Issue 1, pp. 269-281, 2021

The World Economic Forum (WEF, 2017) was focused on the impact of innovation and new technologies in oil and gas industry and it recommended for oil and gas industry - somehow declarative but very todated - to push for automation, remote operations via end-to-end processes connected through Industrial Internet of Things (IIoT), advance analytics and modeling tools, connected worker technologies, and development of innovation culture inside the organizations.

A defining particularity of the oil and gas organizations is emphasized by McCarthy (2018): their strategic thinking is challenged by crucial decisions that have to solve the problem of improving their operational efficiency, and, in the same time, facing the challenge of reducing the environment carbon footprint. This challenge requires huge investments to be made in digitalization of operations (estimated at 1 billion USD by the end of 2023).

Another characteristic of oil and gas industry as result of the Industry 4.0 impact is disruption in the upstream business (Fraser, Anastaselos and Ravikumar, 2018). The Introduction of their study reads: "the disruptive potential arising from the point deployment of Internet-of-Things, robotics, artificial intelligence, and other advanced technologies is projected to be over UD\$300 trillion over the next decade" (2018-2028). These huge financial figures demonstrate the central economic importance of the oil and gas industry, on one hand, and (on the other) the crucial importance of strategic decisions (all related to the digital transformation) made in this industrial sector.

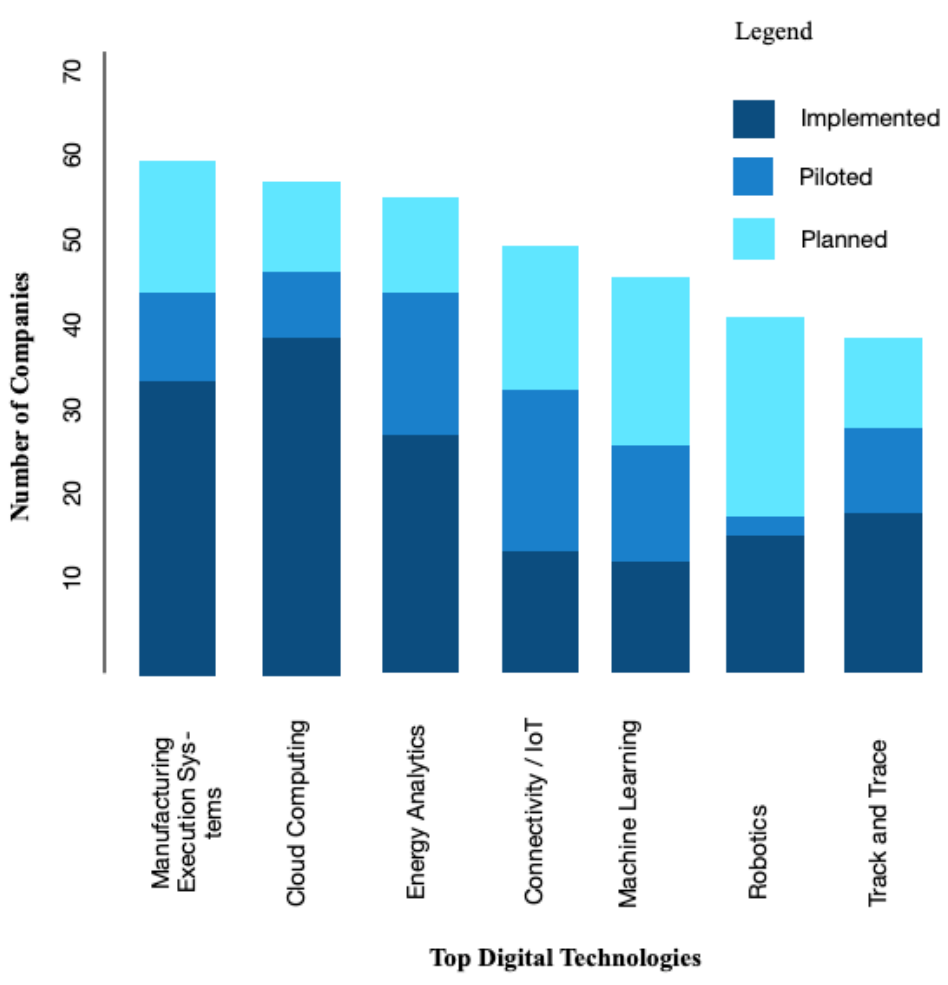

Figure 3. Global ranking of companies from oil and gas industry - as far as implementation of dominant digital technologies. Adapted from: Pandey and Branson (2020)

According to a study conducted by the PricewaterhouseCoopers' strategy consulting business among over 200 oil and gas global companies (Pandey and Branson, 2020), most executives from oil and gas industry are familiar with the benefits of digitalization, which will generate increased revenue and decrease in costs due to higher operational efficiency and larger production. According to the same study, the top five drivers of the digital transformation are the following: manufacturing execution system, cloud computing, energy 
analytics, internet of things (IoT), and machine learning technologies designed for operations efficiency and sustainability (Figure 3). The same figure exhibits the ranking of the top seven digital technologies (considered as drivers of the digital transformation) - as far as the implementation status - according to a study completed Robotics and robotization also makes the top five drivers of the digital transformation as far as already implemented technologies, next to manufacturing execution system, cloud computing, energy analytics, and IoT.

As opposed to the global picture (described in Figure 3), Table 1 depicts the position of the Romanian oil and gas industry (represented by two prominent companies - conventionally named Ro1 and Ro1, for confidentiality reasons). The implementation stage of the same digital key-technologies was assessed in early 2020, during interviewing a panel of thirteen experts (industry executives and consultants), on a similar qualitative (but finer), five points scale (partially planned, strategically planned, piloted, implementation in progress, implemented).

Table 1. Digital technologies implementation by two leading Romanian oil and gas companies - as compared to the global implementation stage

\begin{tabular}{|c|l|l|l|}
\hline \multirow{2}{*}{$\begin{array}{c}\text { No. } \\
\text { crt. }\end{array}$} & $\begin{array}{c}\text { Most implemented digital technologies, globally } \\
- \text { adapted after Pandey and Branson (2020) }\end{array}$ & \multicolumn{2}{|c|}{$\begin{array}{r}\text { Implementation stage by two leading Romanian } \\
\text { oil \& gas companies (own interviews) }\end{array}$} \\
\cline { 3 - 4 } & & Ro 1 & \multicolumn{1}{|c|}{ Ro 2 } \\
\hline 1. & Manufacturing execution systems & Strategically planned & Strategically planned \\
\hline 2. & Cloud Computing & Partially planned & Strategically planned \\
\hline 3. & Energy Analytics & Piloted & In progress \\
\hline 4. & Connectivity / Internet of Things & Partially planned & Partially planned \\
\hline 5. & Machine Learning & Partially planned & Partially planned \\
\hline 6. & Robotics & In progress & In progress \\
\hline 7. & Track and Trace & Strategically planned & Strategically planned \\
\hline
\end{tabular}

According to our study, the two companies assessed are following cost optimization and cost avoidance strategies, focusing more on business processes optimization, using robotics (RPA) technology, and predictive maintenance. The resistance of executives on speeding up the process of digitalization however, a high priority for the long term business strategy, is related to the significant investment in the infrastructure, which is necessary to be done, correlated with the difficulty of quantifying the results and translating them in tangible goals on a timescale.

The comparative analysis of the stage of digital transformation in Romania versus global stage reveals two important findings - both related to strategy thinking and strategic management:

- Existence of a "digital technology gap" (delay in digital transformation) in the Romanian oil and gas industry, twofold - as the two Romanian companies reveal no implemented digital technologies (considering the top seven, most advanced digital technologies, globally); and most of the top seven global technologies are in the planning phase (in several cases not even strategic planning but partial planning).

- Disputable priority settings (or priority divergence) - as the most advanced digital technologies to be implemented by the Romanian oil and gas companies are the robotics and energy analytics (still in progress or just piloted), as compared to the most advanced globally (manufacturing execution systems and cloud computing).

Both findings have, besides economic consequences, managerial implications as well. 
Another finding of the explorative research conducted in Romania is related to the maturity of the digital operations, maturity being defined considering four levels of digital operations: digital champion, digital innovator, digital follower, and digital novice (Table 2). According to Pandey and Branson (2020, p.5), only $7 \%$ consider themselves to be digital champions and over $70 \%$ "considered themselves to be in the early stages of digital maturity - that is, either Digital Novices or Digital Followers".

The interviews conducted in Romania concluded that the two Romanian oil and gas companies investigated (Ro1 and Ro2) are finding themselves more as digital followers but with a slight penchant to digital innovators on few particular areas such as non-fuel retail (Table 2).

Table 2. Maturity of the digital operations of two leading Romanian oil and gas companies - as compared to the maturity of the digital operations in the same industry, globally

\begin{tabular}{|c|c|c|c|c|}
\hline \multirow{2}{*}{$\begin{array}{l}\text { No. } \\
\text { crt. }\end{array}$} & \multicolumn{2}{|c|}{$\begin{array}{l}\text { Digital operations in the global oil and gas industry - } \\
\text { adapted after Pandey \& Branson (2020) }\end{array}$} & \multicolumn{2}{|c|}{$\begin{array}{l}\text { Digital operations of the Romanian oil } \\
\text { \& gas companies (own interviews) }\end{array}$} \\
\hline & Maturity level & Percentage & Ro 1 & Ro 2 \\
\hline 1. & $\begin{array}{l}\text { Digital Champion: } \\
\text { The company has a clear position in the } \\
\text { marketplace with complex and tailored } \\
\text { internal, partner and customer solutions } \\
\text { offered via multilevel digital interaction }\end{array}$ & $7 \%$ & - & - \\
\hline 2. & $\begin{array}{l}\text { Digital Innovator: } \\
\text { The company has digitized most internal } \\
\text { operations and taken steps to connect } \\
\text { with external partners/ customers to } \\
\text { exchange information and collaborate }\end{array}$ & $22 \%$ & $\begin{array}{c}\text { Digital innovator } \\
\text { in particular areas } \\
\text { (non-fuel retail) }\end{array}$ & $\begin{array}{c}\text { Digital innovator } \\
\text { in particular areas } \\
\text { (non-fuel retail) }\end{array}$ \\
\hline 3. & $\begin{array}{l}\text { Digital Follower: } \\
\text { The company has integrated internal } \\
\text { functions such as sales, manufacturing, } \\
\text { sourcing and engineering, enabling them } \\
\text { to collaborate more closely }\end{array}$ & $36 \%$ & $\begin{array}{l}\text { Digital follower } \\
\text { mostly }\end{array}$ & $\begin{array}{l}\text { Digital follower } \\
\text { mostly }\end{array}$ \\
\hline 4. & $\begin{array}{l}\text { Digital Novice: } \\
\text { The company has some isolated digital } \\
\text { solutions and applications, but these } \\
\text { exist at the functional or departmental } \\
\text { level within the organisation }\end{array}$ & $35 \%$ & & \\
\hline
\end{tabular}

The comparative analysis of the above findings shows an average position (advanced followers) of the two Romanian companies, with no digital champion, no digital novice.

On the way to becoming digital champions, the main issues that global oil and gas companies are facing are (Pandey and Branson, 2020, p.9): (i) inability to identify and focus on business priorities to be addressed through digital applications; (ii) lack of capabilities, in particular to develop and deploy digital tools and applications; (iii) outdated processes and organizational structures; (iv) weak or no digital operating model to drive digital transformation; (v) lack of an agile culture that involves collaboration and knowledgesharing (new ways of working, in general). 


\section{Conclusions and managerial implications}

The fourth industrial revolution, namely Industry 4.0, is based on the information and communication technology (ICT). The four defining features of Industry 4.0 are identified in the oil and gas industry.

All industries are more or less dependent and/or influenced by ICT solutions to ensure sustainability and competitive advantage; nevertheless, the oil and gas industry, as all energy sector, is the strategic key for the future sustainable development.

The ICT focus of the organizations from oil and gas industry becomes an important characteristic of their strategy. If ICT solutions are used as a response to the organization's dynamic challenges, and if strategic thinking represents the mental process of finding opportunities to achieve the organization's goals, then conclusion is that ICT continuously does influence strategic thinking in the oil and gas industry.

The strategic thinking of the organizations active in the oil and gas organizations is challenged by crucial decisions that have to solve the problem of improving their operational efficiency, and, in the same time, facing the challenge of reducing the environment carbon footprint. Their top managers have to make strategic decisions related to the huge investments to be made in digitalization of operations, aiming at developing the Industrial Internet of Things (IIoT).

In addition, there is a big uncertainty - as oil and gas organizations are in a difficult position to strategically plan the future, based on the multiple challenges they are facing. COVID-19 pandemic, political measures taken regarding climate change, electrical vehicles market increase are factors that are forcing the leaders of oil and gas industry to respond quickly (make rapid decisions - which is somehow in contradiction with longer term strategic decisions).

From the management standpoint, there are three important implications of the research findings, all related to managing the digital transformation within the Romanian oil and gas companies: (i) accelerated digital transformation, supported by strategic decisions related to longer-term, significant investments in digital technologies, in harmony with the global trends; (ii) improved priority setting related to digital technologies implementation, aligned to global champions of digital operations; (iii) improved design and implementation of the digital transformation projects (i.e. better project management), based on higher skilled human resource as well as newer, flexible methods (as agile) and strategies.

\section{Limitations and further research paths}

As research in progress (inception phase of a larger research project), the paper has inherent limitations; the next step aims at getting more quantitative results, by opening future research paths both longitudinally and transversally in oil and gas industry: focus on specific case to watch the evolution of the company's strategy in time, under the influence of new technologies; comparing current strategies of different actors active in the oil and gas industry, in a particular country (Romania).

As the coronavirus pandemic is at its apex, and it continues to challenge the world economies, it would be appealing to study if this pandemic acts as a digital technology accelerator in industry in general (Scarlat, 2021; Scarlat and Stănciulescu, 2021; Scarlat, Stănciulescu and Panduru, 2021) - and, therefore, a change agent for strategic changes, in oil and gas industry as well.

The future research should also consider that dynamics of the digital transformation, unparalleled to none, has its own dynamics, and the Industry 4.0 is going to be succeeded by the Industry 5.0 (Longo, Padovano and Umbrello, 2020), which propose a "human-centric perspective" while designing the factory of the future, and the concept of ethical technology engineering. 


\section{Issues in Information Systems}

Volume 22, Issue 1, pp. 269-281, 2021

\section{References}

Ansoff, H.I. (1965) Corporate Strategy. An Analytic Approach to Business policy for Growth and Expansion. New York: McGraw-Hill.

Ansoff, H.I. (1979) Strategic Management. London, UK: Palgrave MacMillan.

Ansoff, H.I. (1987) Strategic Management of Technology. IEEE Engineering Management Review, 15(3), 2-13.

Ansoff, I. (1988) The New Corporate Strategy. Hoboken, NJ, USA: John Wiley \& Sons.

Ansoff, I. (1991) Critique of Henry Mintzberg's The design school: reconsidering the basic premises of strategic management. Strategic Management Journal, 12(6), 449-461.

Ansoff, H.I, Antoniou, P.H. (2006) The Secrets of Strategic Management: The Ansoffian Approach. BookSurge Publishing. First published by Ansoff Institute in 2005.

Ansoff, H.I., Kipley, D., Lewis, A., Helm-Stevens, R., Ansoff, R. (2019) Implanting Strategic Management. Third Edition. London, UK: Palgrave MacMillan.

Chandler, A.-Jr. (1962) Strategy and Structure: Chapters in the History of the American Industrial Enterprise. Cambridge, MA, USA: The Massachusetts Institute of Technology - MIT Press.

Dickson, D. (2021) 2021 oil and gas industry outlook. [online: https://www2.deloitte.com] Retrieved 7 March 2021 from: https://www2.deloitte.com/us/en/pages/energy-and-resources/articles/oil-andgas-industry-outlook.html

Doer, J. (2018) Measure What Matters. How Google, Bono, and the Gates Foundation Rock the World with OKRs. New York, USA: Bennett Group, LLC.

Drucker, P. (1954) The Practice of Management. New York: Harper \& Brothers.

Drucker, P. (1964) Managing for Results. New York: Harper \& Row.

Drucker, P. (1971) Drucker on Management. London: Management Publications, Ltd.

Drucker, P. (1980) Managing in Turbulent Times. New York: Harper \& Row.

Drucker, P. (1985) Innovation and Entrepreneurship. New York: Harper \& Row.

Drucker, P. (1995) Managing in a Time of Great Change. New York: Truman Talley Books/Dutton.

Fayol, H. (1917) Administration industrielle et générale; prévoyance, organisation, commandement, coordination, contrôle. Paris: H. Dunod et E. Pinat.

Fraser, M.S., Anastaselos, T. and Ravikumar, G.V.V. (2018) The disruption in oil and gas upstream business by Industry 4.0. White Paper. Infosys Limited. [online: www.infosys.com] Retrieved 5 March 2021 from:

https://www.infosys.com/engineering-services/white-papers/documents/disruption-oil-gasupstream.pdf

Gantt, H.L. (1916) Industrial Leadership. New Haven: Yale University Press. 


\section{Issues in Information Systems}

Volume 22, Issue 1, pp. 269-281, 2021

Geissbauer, R., Vedso, J., Schrauf, S. (2016) Industry 4.0: Building the digital enterprise. 2016 Global Industry 4.0 Survey. PricewaterhouseCoopers. Retrieved 5 April 2021 from: https://www.pwc.com/gx/en/industries/industries-4.0/landing-page/industry-4.0-building-yourdigital-enterprise-april-2016.pdf

Goldman, E.F. (2012) Leadership practices that encourage strategic thinking. Journal of Strategy and Management, 5(1), 25-40.

Hamel, G.P., Prahalad, C.K. (1994) Competing for the Future. Boston, MA, USA: Harvard Business School Press.

Haycock, K., Cheadle, A. and Bluestone, K.S. (2012) Strategic thinking and leadership. Library leadership \& management, 26(3/4), 1-23.

Heracleous, L. (1998) Strategic Thinking or Strategic Planning? Long Range Planning, 31(3), 481-487.

Kaplan, R.S., Norton, D.P. (2001) The Strategy-Focused Organization. How Balanced Scorecard Companies Thrive in the New Business Environment. Boston, MA, USA: Harvard Business School Press.

Kazmi, A. and Kazmi, A. (1992) Strategic Management. 1st edition. New York, USA: McGraw-Hill Education.

Kim, W.C., Mauborgne, R. (2004) Blue Ocean Strategy. How to Create Uncontested Market Space and Make the Competition Irrelevant. Boston, MA, USA: Harvard Business Review Press.

Kumar, N. (2004) Marketing as Strategy: Understanding the CEO's Agenda for Driving Growth and Innovation. Boston, MA, USA: Harvard Business School Press.

Levinthal, D. and March, J. (1993) The Myopia of Learning. Strategic Management Journal, 14(1), 95112.

Longo, F., Padovano, A. and Umbrello, S. (2020) Value-Oriented and Ethical Technology Engineering in Industry 5.0: A Human-Centric Perspective for the Design of the Factory of the Future. Applied Sciences, 10(12), 4182, Published: 18 June 2020; https://doi.org/10.3390/app10124182

Loveridge, D. (2003) Foresight: The Art and Science of Anticipating the Future. Milton Park, UK: Taylor and Francis.

Martinet, A.-C. (2010) Strategic planning, strategic management, strategic foresight: The seminal work of H. Igor Ansoff. Technological Forecasting and Social Change, 77(9), 1485-1487.

McCarthy, D. (2018) IoT and Digitalization of Oil and Gas Production. Pipeline \& Gas Journal, 245(2), 49-51.

Mintzberg, H. (1994) The Rise and Fall of Strategic Planning. Harvard Business Review, 72(1), JanuaryFebruary 1994, 107-114.

Mintzberg, H. (2013) The Rise and Fall of Strategic Planning. New York: The Free Press.

Mintzberg, H., Ahlstrand, B.B., Lampel, J. (1998) Strategy Safari: A Guided Tour through the Wilds of Strategic Management. New York: The Free Press. 


\section{Issues in Information Systems}

Volume 22, Issue 1, pp. 269-281, 2021

Montanus, M. (2016) Business Models for Industry 4.0: Developing a Framework to Determine and Assess Impacts on Business Models in the Dutch Oil and Gas Industry. [online: https://repository.tudelft.nl] Retrieved 7 March 2021 from: https://repository.tudelft.nl/islandora/object/uuid\%3A3177d804-06d5-455c-a508-87222c1d602a

Moussetis, R. (2011) Ansoff revisited. How Ansoff interfaces with both the planning and learning schools of thought in strategy. Journal of Management History, 17(1), 102-125.

Pandey, A. and Branson, D. (2020) 2020 Digital Operations study for energy. [online: https://www.strategyand.pwc.com] Retrieved 5 March 2021 from: https://www.strategyand.pwc.com/gx/en/insights/2020/digital-operations-study-for-oil-andgas/2020-digital-operations-study-for-energy-oil-and-gas.pdf

Popescu, F. and Scarlat, C. (2015) Limits of SWOT analysis and their impact on decisions in early warning systems. Proceedings of the 7th International Conference on SEA Events (Sharing, Empower, Awareness) - "Interdisciplinary approaches between traditional and modern methods". 24th-25th of April, 2015. Iași, Romania: The Romanian Academy.

Popper, R. (2008) Foresight Methodology. In The Handbook of Technology Foresight-Concepts and Practices (Editors: Luke Georghiou, Jennifer Cassingena Harper, Michael Keenan, Ian Miles, and Rafael Popper), 44-88. Chelteham, UK: Edward Elgar.

Porter, M. (1986) Competitive Strategy: Techniques for Analyzing Industries and Competitors. Boston, MA, USA: Harvard Business School Press.

Porter, M. (1996) What is Strategy? Harvard Business Review, 74(6), November-December 1996, 61-78.

Satell, G. (2020) You Don’t Need a Grand Strategy to Achieve Organizational Change. Harvard Business Review, March 10, 2020. [online: https://hbr.org] Retrieved 7 March 2021 from: https://hbr.org/2020/03/you-dont-need-a-grand-strategy-to-achieve-organizational-change

Scarlat, C. (2015) Organization and its limits: three major managerial implications. Volume for the 7th International Conference on SEA events (Sharing, Empower, Awareness) International Conference - "Interdisciplinary approaches between traditional and modern methods" (Editor-inChief: Dan Serghie), 24th-25th of April 2015. Iași, Romania: The Romanian Academy, 67-74.

Scarlat, C. (2021) “Today's Higher Education at a Crossroads. The Critical Point and Paradigm Shift in the Educator's Role". Chapter 23 in Education Applications \& Developments - EAD VI (Editor: Mafalda Carmo). WIARS, Lisbon, Portugal: InScience.

Scarlat, C., Stănciulescu, G.D. (2021) "Covid-19 Pandemic: Threat or Accelerator? The Case of Romanian Book Publishing Industry". Chapter 6 in Co-creating the Post COVID-19 World: Exploring Sustainable Paths (Editors: Dr Mohammed Al Haziazi, Dr Amer Al Hajri, Dr Kabaly P Subramanian, Dr Subrahmanian Muthuraman). Muscat, Oman: Arab Open University.

Scarlat, C., Stănciulescu, D.G. and Panduru, D.A. (2021) Covid-19 Pandemic: Threat, Opportunity or Accelerator? From Strategy Accelerator to Digital Acceleration. Proceedings of the $37^{\text {th }}$ IBIMA (International Business Information Management Association) Conference, 1-2 April 2021, Cordoba, Spain.

Schlaepfer, R., Koch, M. and Merkofer, P. (2015) Industry 4.0: Challenges and solutions for digital transformation and use of exponential technologies. [online: https://www2.deloitte.com] Retrieved 7 March 2021 from: 


\section{Issues in Information Systems}

Volume 22, Issue 1, pp. 269-281, 2021

https://www2.deloitte.com/content/dam/Deloitte/ch/Documents/manufacturing/ch-enmanufacturing-industry-4-0-24102014.pdf

Schwab, K. (2017) The Fourth Industrial Revolution. New York: Crown Publishing Group.

Shekhar, V. (2009) Perspectives in Strategic Management. A Critique of Strategy Safari: The Complete Guide through the Wilds of Strategic Management. ICFAI Journal of Business Strategy, 6(2), 4355.

Taylor, F.W. (1911) The Principles of Scientific Management. New York, USA and London, UK: Harper \& Brothers.

WEF (2017) Digital Transformation Initiative Oil and Gas Industry. World Economic Forum - WEF. [online: https://reports.weforum.org] Retrieved 5 March 2021 from: https://reports.weforum.org/digital-transformation/wpcontent/blogs.dir/94/mp/files/pages/files/dti-oil and-gas-industry-white-paper.pdf

Wootton, S. and Horne, T. (2001) Strategic Thinking: A Step-by-step Approach to Strategy. 2nd edition. London, UK: Kogan Page Publishers. 